\title{
PRODUCTS OF ALKALI-ACTIVATED CALCAREOUS FLY ASH AND GLASS CULLET
}

\author{
I. Papayianni ${ }^{1}$, S. Konopisi ${ }^{2}$, K. Datsiou ${ }^{3}$, F. Kesikidou ${ }^{4}$ \\ ${ }^{1}$ Laboratory of Building Materials, Dept of Civil Engineering, Aristotle University of Thessaloniki (AUTH), \\ Thessaloniki, Greece. \\ ${ }^{2}$ Laboratory of Building Materials, Dept of Civil Engineering, Aristotle University of Thessaloniki (AUTH), \\ Thessaloniki, Greece. \\ ${ }^{3}$ Laboratory of Building Materials, Dept of Civil Engineering, Aristotle University of Thessaloniki (AUTH), \\ Thessaloniki, Greece. \\ ${ }^{4}$ Laboratory of Building Materials, Dept of Civil Engineering, Aristotle University of Thessaloniki (AUTH), \\ Thessaloniki, Greece.
}

\begin{abstract}
Geopolymerisation comprises a promising field of research, which deals with the rich in aluminosilicates solid wastes and byproducts (such as fly ash, recycled glass cullet), which are converted into useful products via alkaline activation process and heat curing. The fly ash used in this study is a calcareous one, which is the only type produced in Greece from the combustion of lignite. In this paper, mixtures of fly ash with glass cullet, deriving from windshields, are investigated and in particular, the mechanical characteristics and physical properties of colored mixtures that may be used for the manufacture of precast products Four trial mixes were studied experimentally, by forming prismatic $(40 \times 40 \times 160 \mathrm{~mm})$ specimens and small slabs $(200 \times 200 \times 25 \mathrm{~mm})$. The tests of the prismatic specimens include the determination of the compressive and flexural strength, the elastic properties and the porosity at 7-d, 28-d and 90-d age. Volume deformation measurements were also carried out at 28-d age. The mechanism of strength development was monitored by using SEM microscopy, X-ray diffractometer and FTIR spectroscopy. The small slabs were tested in relation to their resistance to abrasion, impact strength, flexural strength and physico-chemical properties.
\end{abstract}

Keywords: Calcareous fly ash, glass cullet, alkali-activation, mechanical strength, physic-chemical properties $* * *$

\section{INTRODUCTION}

In recent decades, demands of the construction industry for cost saving and low environmental foot print have intensified investigations on utilization of industrial by products in an effort to reduce the cost of their dumping and minimize distribution costs. Under this prism, by-products rich in aluminum and silicon could be transformed into inorganic aluminosilicate gel known as geopolymers.

The geopolymers are inorganic polymeric materials developed by J. Davidovits in 70s and involve the chemical reaction of alumino-silicate oxides with alkali polysilicates yielding polymeric $\mathrm{Si}-\mathrm{O}-\mathrm{Al}$ bonds [1].The procedure of geopolymerisation takes place by alkaline activation with alkaline aqueous solutions rich in soluble silica. Final products gain very good mechanical and physicochemical properties that could find different applications in construction.

The mechanisms proposed for the geopolymerization includes dissolution of $\mathrm{Si}$ and $\mathrm{Al}$, formation of oligomers species, polycondensation of the oligomers to form framework and hardening of the whole system into a final solid polymeric structure [2]-[4]. According to this, another form of self strengthening material consisting of silicon and aluminum activated in a high alkali solution is developed [5].
This load bearing material could be based on low cost fly ash as a raw material and termed as geopolymer or alkaliactivated fly ash cement [6]-[8].

As known, fly ash is a solid by-product emanating by the combustion of coal. Its appearance is light to dark-gray powder and has very fine granulometry. Fly ashes are distinguished between Class F - low calcium and Class C high calcium ones according to ASTM C618. Class C often contains calcium aluminates and calcium silicates, apart from other compounds, and present both pozzolanic and cementitious properties [9]. Fly ashes Class C, especially from the combustion of lignite coal, usually contain more than $10 \% \mathrm{CaO}$, lower content in silica and alumina, compared to Class F fly ashes, but also contain higher amounts of sulphates mostly in the form of sodium sulphate. [9].

The fly ash used in this paper may be characterized as calcareous fly ash due to its high calcium and free calcium content. The purpose of this research was to examine the adequacy of the Greek fly ash and its potential use, through the mechanism of alkali-activation, in precast materials [10]. The addition of recycled glass cullet, derived from windshields, is another feature of this paper. Glass cullet as aggregates and their contribution to the mechanical characteristics and the aesthetic value of the coloured mortar 
mixes were examined. Finally, small slabs were produced and tested according to relevant European Standards.

\section{EXPERIMENTAL}

\subsection{Materials}

The raw materials used were the following: Fly ash (F) from the power station Agios Dimitrios in north Greece, standard sand, and recycled glass cullet (G) deriving from windshields, sodium hydroxide, sodium silicate solution, plasticizer, pigments and water. The macroscopic images of raw materials are shown in Figure 1.

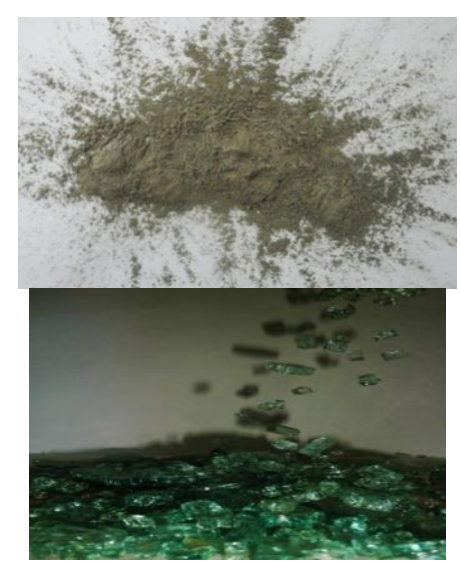

Fig. 1: Macroscopic images of (a) fly ash and (b) glass aggregates

The chemical composition of fly ash (F) and glass cullet (G) determined by Atomic Absorption Spectrometry, AAS, according to EN 451-1 are given in Table 1.

Table 1: Chemical composition of raw materials (\% w.t.)

\begin{tabular}{|l|l|l|}
\hline & Fly ash (F) & Glass cullet $(\mathrm{G})$ \\
\hline $\mathrm{SiO}_{2}$ & 27.23 & 73.53 \\
\hline $\mathrm{Al}_{2} \mathrm{O}_{3}$ & 13.30 & 0.79 \\
\hline $\mathrm{CaO}$ & 36.38 & 10.12 \\
\hline $\mathrm{Fe}_{2} \mathrm{O}_{3}$ & 5.35 & 0.90 \\
\hline $\mathrm{MgO}$ & 3.55 & 3.58 \\
\hline $\mathrm{SO}_{3}$ & 7.48 & 0.50 \\
\hline $\mathrm{Na}_{2} \mathrm{O}$ & 0.27 & 9.57 \\
\hline $\mathrm{K}_{2} \mathrm{O}$ & 0.84 & 0.22 \\
\hline $\mathrm{L}$. o.I. & 5.56 & 0.29 \\
\hline $\mathrm{CaO}$ & 11.10 & - \\
\hline
\end{tabular}

The results from the chemical analysis show a high percentage of $\mathrm{CaO}$ (as total) and $\mathrm{CaO}_{\text {free }}$ which classifies the fly ash as a high calcium one, which does not meet existing regulations about class $\mathrm{C}$ fly ashes (ASTM C618).

Mineralogical analysis of fly ash by X-Ray Diffraction (XRD) is presented in Chart 1 .

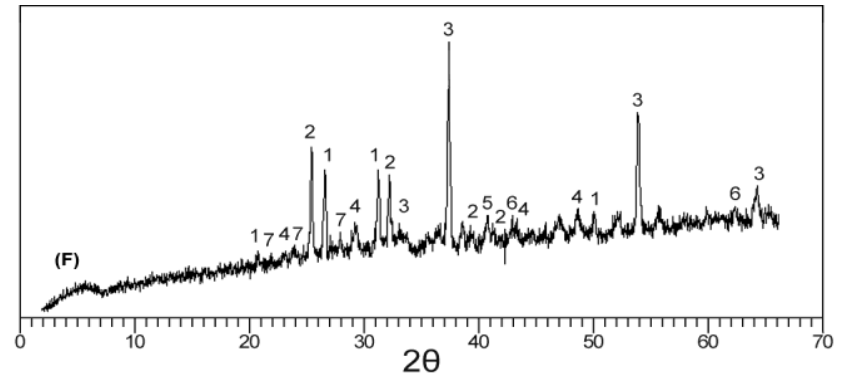

Chart 1: XRD diagram of fly ash F; (1) quartz, (2) anhydrite, (3) lime, (4) calcite, (5) mullite, (6) periclase, (7) feldspars.

The raw fly ash is constituted of quartz, lime, anhydrite, and some minor crystalline phases such as calcite, periclase, mullite, and feldspars such as albite and anorthite.

Particle size analysis of this fly ash is shown in Chart 2.

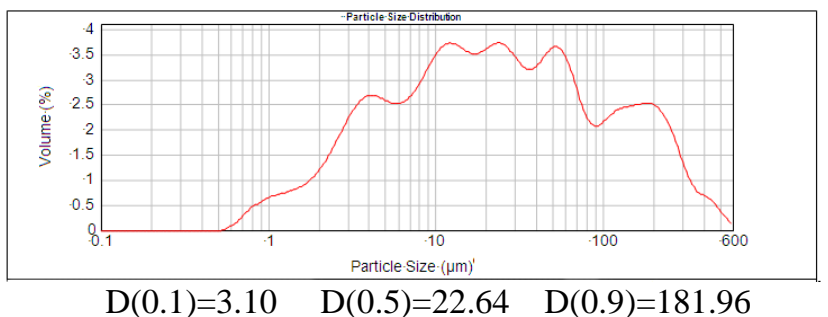

Chart 2: Particle size distribution (F); Specific Surface Area $=0.734 \mathrm{~m}^{2} / \mathrm{g}$, wide dispersion of grains mainly from 2$200 \mu \mathrm{m}$

The grinding fineness of the fly ash was tested according to ASTM C430. The retained rate in the $45 \mu \mathrm{m}$ sieve was $35 \%$. Furthermore, as described in ASTM C128-01, the apparent specific weight of the fly ash and the glass cullet was found 2.373 and 2.525 respectively.

From the granulometric analysis of the glass (Table 2), it was found that there was a reduced amount of fine material (only $26.51 \%$ found to be less than $4 \mathrm{~mm}$ ) which was replaced by standard sand in a ratio of (3/2) (parts of glass aggregates/ parts of standard sand).

Table 2: Granulometric analysis of glass

\begin{tabular}{|l|l|}
\hline Sieve $(\mathrm{mm})$ & Pass.(\%) \\
\hline 16.0 & 100.0 \\
\hline 8.0 & 99.76 \\
\hline 6.3 & 97.11 \\
\hline 4.0 & 20.15 \\
\hline 2.5 & 3.25 \\
\hline 1.0 & 1.65 \\
\hline 0.5 & 0.91 \\
\hline 0.2 & 0.37 \\
\hline 0.1 & 0.14 \\
\hline 0.063 & 0.04 \\
\hline blind & 0.00 \\
\hline
\end{tabular}

SEM/EDS analysis for the raw fly ash $\mathrm{F}$ is presented in Figure 2. 


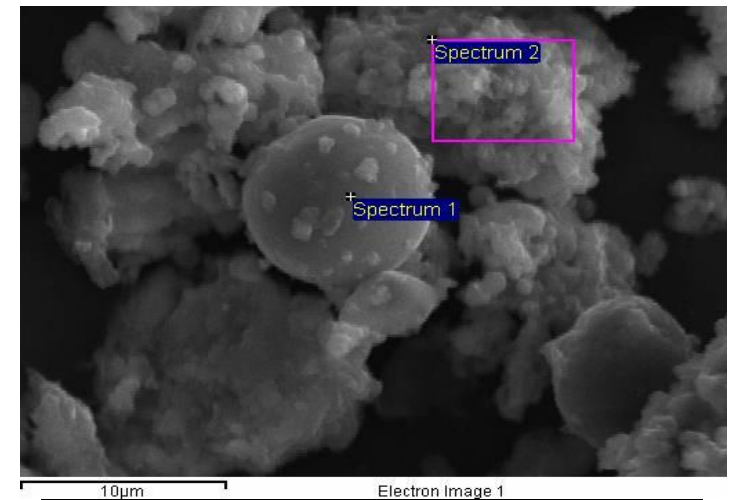

\begin{tabular}{|l|l|l|}
\hline \multicolumn{2}{|c|}{ Electron Image 1 } \\
\hline Spectrum & Spectrum 1 & Spectrum 2 \\
\hline In stats. & Yes & Yes \\
\hline $\mathrm{Na}$ & 1.18 & 0.79 \\
\hline $\mathrm{Mg}$ & 9.49 & 3.77 \\
\hline $\mathrm{Al}$ & 10.38 & 2.25 \\
\hline $\mathrm{Si}$ & 23.77 & 2.25 \\
\hline $\mathrm{S}$ & 5.92 & 26.33 \\
\hline $\mathrm{K}$ & 1.27 & 0.32 \\
\hline $\mathrm{Ca}$ & 45.35 & 64.14 \\
\hline $\mathrm{Fe}$ & 2.66 & 0.15 \\
\hline
\end{tabular}

Fig. 2: SEM/EDS analysis for raw fly ash $\mathrm{F}$

According to Figure 2, the raw fly ash $\mathrm{F}$ was composed by compact spheres (its EDS analysis is shown in Spectrum 1) of different size with an almost regular smooth texture which, are included into the matrix with loose cohesion.

Furthermore, from the EDS analysis the existence of clumps of sulphur-calcite nature is clear in Spectrum 2. In Spectrum $1, \mathrm{Si} / \mathrm{Al}$ ratio reaches the level of 2.3 and $\mathrm{Si} / \mathrm{Ca}$ is about 0.5 , where as other elements are also found such as $\mathrm{Mg}, \mathrm{S}, \mathrm{Fe}$ and in smaller amounts $\mathrm{Na}$ and $\mathrm{K}$.

SEM/EDS analysis for the glass cullet is presented in Figure 3.

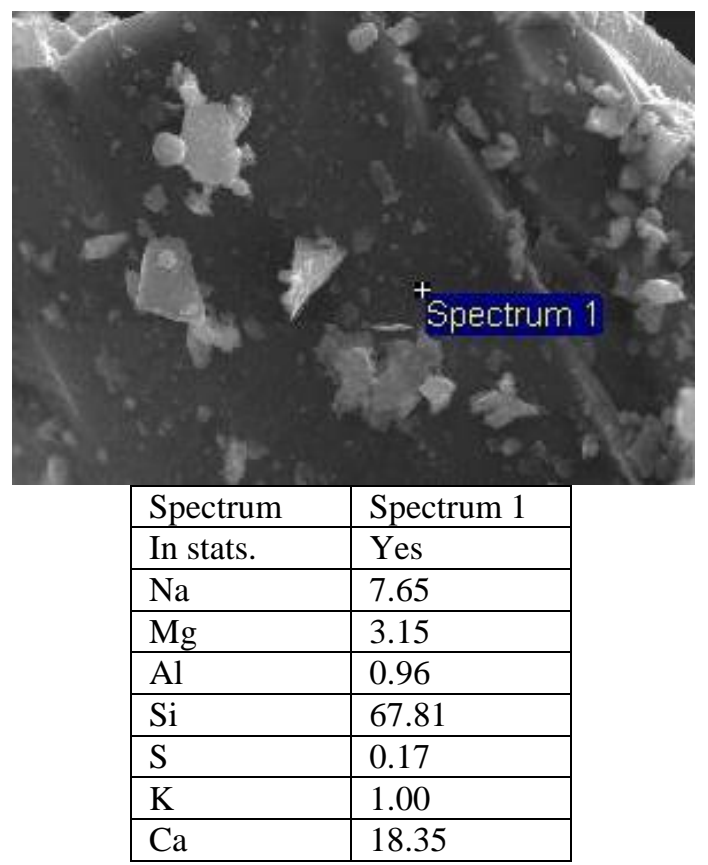

\begin{tabular}{|l|l|}
\hline $\mathrm{Fe}$ & 1.24 \\
\hline
\end{tabular}

Fig. 3: SEM/EDX analysis for glass cullet

From Spectrum 1 of SEM/EDS analysis, which is shown in Figure 3, the EDS analysis of the glass cullet, which was used mostly as aggregates, is confirmed. Clearly, glass consists mainly from silicon while calcium and sodium are also located in less level.

Sodium hydroxide, $\mathrm{NaOH}$ in pellets form $99.5 \%$ purity, water glass (sodium silicate neutral solution: $8.9 \% \quad \mathrm{Na}_{2} \mathrm{O}$, $28.7 \% \mathrm{SiO}_{2}, 62.4 \% \mathrm{H}_{2} \mathrm{O}$ and $\mathrm{d}=1.365$ ) and tap water were also used for the synthesis of paste specimens for alkaliactivation. Sodium hydroxide pellet was dissolved in distilled water to prepare $\mathrm{NaOH}$ solution $10 \mathrm{M}$. The alkaline activator used was a mixture of sodium hydroxide and sodium silicate solution with $\mathrm{NaOH}: \mathrm{Na}_{2} \mathrm{SiO}_{3}$ weight ratio 1:1. A commercially available water reducing admixture (1-2\%) was used to improve workability of fresh mix [11], [12].

\subsection{Composition of Alkali-Activated Mixtures}

\section{Tested}

Sodium hydroxide first was mixed with sodium silicate solution and tap water in order to prepare the liquid phase (18\% $\mathrm{NaOH}$ solution, $18 \% \quad \mathrm{Na}_{2} \mathrm{SiO}_{3}$ solution and $64 \%$ water).

All the produced mixtures and the composition constituents are listed in Table 3.

Table 3: List of fresh mixtures

\begin{tabular}{|l|l|l|l|l|l|l|}
\hline & \multicolumn{6}{|c|}{ Composition constituents, by mass (Kg) } \\
\hline $\begin{array}{l}\text { Fresh } \\
\text { M/re }\end{array}$ & $\begin{array}{l}\text { Fly } \\
\text { ash }\end{array}$ & $\begin{array}{l}\text { Glass } \\
\text { ag/tes }\end{array}$ & Sand & $\begin{array}{l}\text { Alkaline } \\
\text { solution }\end{array}$ & $\begin{array}{l}\text { Pink } \\
\text { Pig/nt }\end{array}$ & Pl/zer \\
\hline FA-W & 1 & - & 3 & $0.78^{*}$ & - & - \\
\hline FA & 1 & - & 3 & 0.80 & - & - \\
\hline $\begin{array}{l}\text { FA }_{100^{-}} \\
\text {G }\end{array}$ & 1 & 1.8 & 1.2 & 0.50 & - & 0.01 \\
\hline $\begin{array}{l}\text { FA }_{90^{-}} \text {G } \\
\text { pink }\end{array}$ & $0.9^{* *}$ & 1.8 & 1.2 & 0.60 & 0.1 & 0.02 \\
\hline
\end{tabular}

* Only water $(\mathrm{W})$

** Fly ash was used reduced at $90 \%$ of the amount of the initial mixture

Fly ash and sand were used in a ratio 1:3 in the first two mortars (FA-W, FA) while for the other two $\left(\mathrm{FA}_{100^{-}} \mathrm{G}, \mathrm{FA}_{90^{-}}\right.$ $\mathrm{G}_{\text {pink }}$ ) a part of sand was replaced by glass aggregates. In the $\mathrm{FA}_{90}-\mathrm{G}_{\text {pink }}$ the percentage of the fly ash was reduced and $10 \%$ of a pigment was added for coloring the mixture. The amount of liquid was determined by the flow table test, in order to achieve the required workability $(11 \pm 1 \mathrm{~cm})$.

The fresh mixtures were placed into metallic moulds in order to prepare $(40 \times 40 \times 160) \mathrm{mm}$ specimens and were cured in an oven $65{ }^{\circ} \mathrm{C}$ for 2 days. After the heating, the specimens were removed from the moulds were left at indoor conditions (RH $95 \pm 5 \%, 25^{\circ} \mathrm{C}$ ) (Figure 4). 


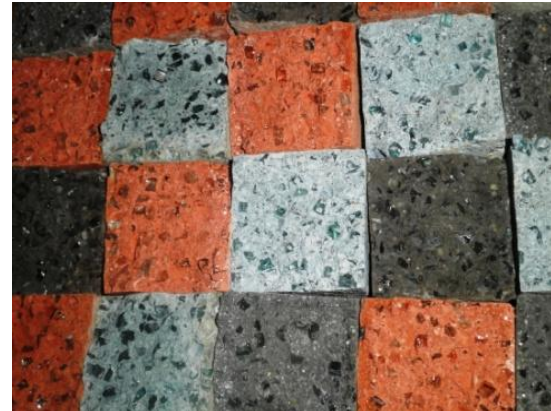

Fig. 4: Samples of the prismatic specimens

Finally, an adequate number of slabs (200x200x25) mm were manufactured with the mixture $\mathrm{FA}_{90}-\mathrm{G}_{\text {pink }}$ and the addition of three different pigments (tawny pink, cobalt blue and iron black) (Figure 5).

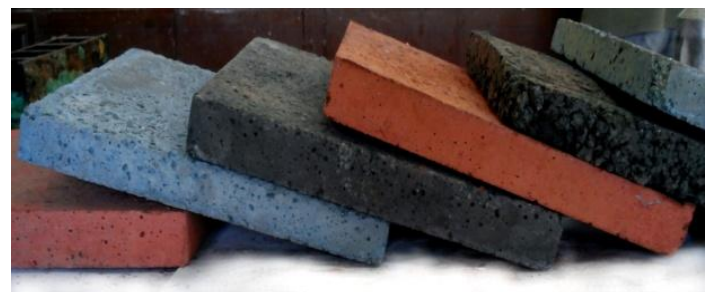

Fig. 5: Slabs 200x200x25 (mm)

\subsection{Tests}

The determination of mechanical strengths (flexural and compressive) was performed in digital testing machines at age 7-d, 28-d and 90-d according to EN 196-1. The RILEM CPC 11.3 method was used to measure open porosity. The volume deformations were monitored by using extensometers at age 28 -d.

In addition, a number of slab samples were examined to determine the flexural strength, at age 7-d, 28-d and 90-d according to EN 1339. Resistance to abrasion, impact strength, resistance to freezing and thawing and water absorption measurements were done according to EN 1338.

\section{RESULTS AND DISCUSSION}

\subsection{Testing Mortar Mixtures (40x40x160 (mm))}

\subsubsection{Mechanical Strengths}

Mechanical strengths (Charts 3-4) of fly ash-based mixtures are presented in the following histograms.

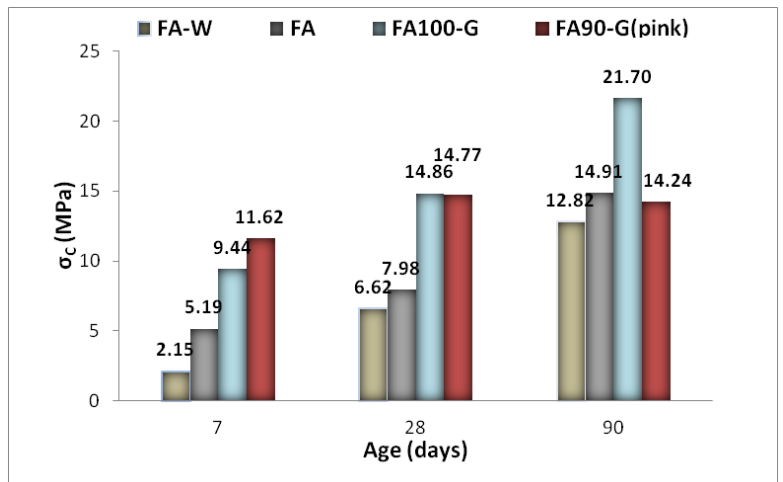

Chart 3: Compressive strength of FA-W, FA, FA $100-\mathrm{G}$ and $\mathrm{FA}_{90}$ Gpink mixtures

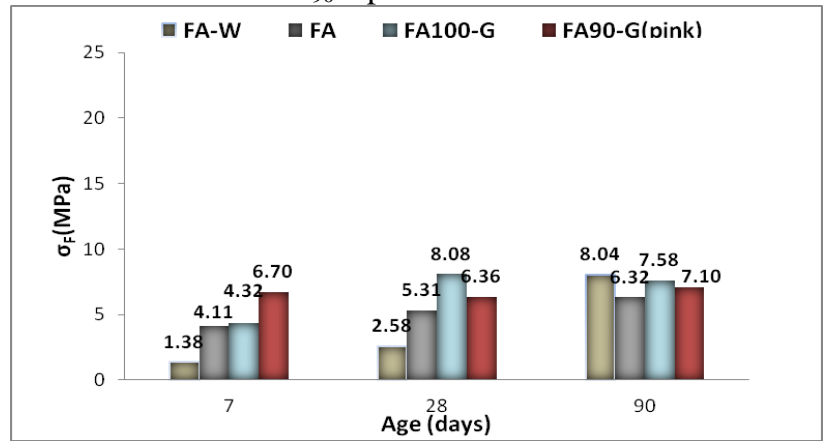

Chart 4: Flexural strength of FA-W, FA, $F_{100}-$ G and FA 90 Gpink mixtures

Generally, an increase of the compressive and flexural strength for all the mixtures is observed with time. Net fly ash without any alkali-activation develops a 28 -d strength of 6.6 $\mathrm{MPa}$ at this fly ash/water ratio (0.78). The addition of the alkaline activator and the glass aggregates give much more improved results, especially in the first days of the curing.

At 28-d age, a strength level of $15 \mathrm{MPa}$ is developed. Similar increase is observed in flexural strength which reaches 6-8 $\mathrm{MPa}$ at 28 days. This extra mechanical strength is probably due to the alkali-activation of the mixtures $\left(\mathrm{FA}, \mathrm{FA}_{100}-\mathrm{G}\right.$, $\mathrm{FA}_{90} \mathrm{G}_{\text {pink }}$ ) and precipitation of amorphous aluminosilicate gel (N-A-S-H) [6], [12].

At the ages of 28 and 90 days, the $\mathrm{FA}_{100}-\mathrm{G}$ mixture shows better results than the $\mathrm{FA}_{90} \mathrm{G}_{\text {pink }}$ mixture, in which $10 \%$ of the fly ash was replaced with a pigment. Obviously, the liquid/solid (L/S) ratio was responsible for this, as in the $\mathrm{FA}_{90} \mathrm{G}_{\text {pink }}$ mixture, more liquid and $2 \%$ of the plasticizer was required workability.

\subsubsection{Open Porosity}

Chart 5 , shows the results of open porosity test during time of all mixtures. 


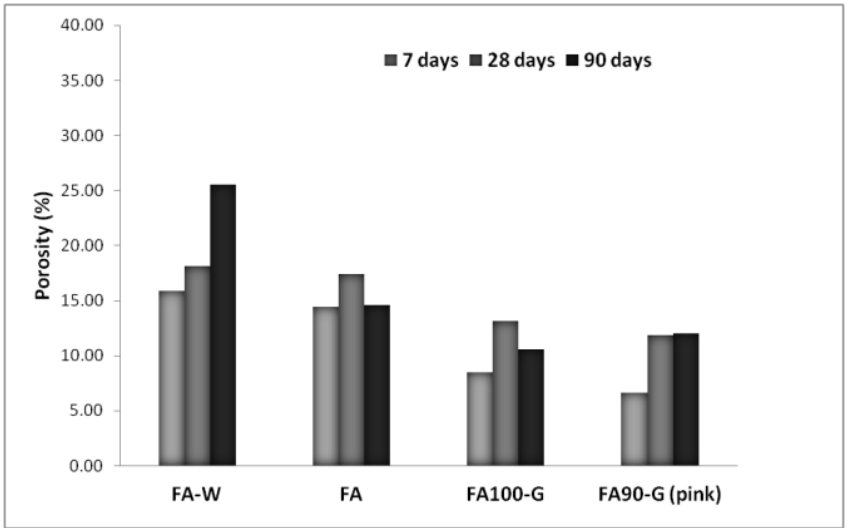

Chart 5: Open porosity of FA-W, FA, $\mathrm{FA}_{100}-\mathrm{G}$ and $\mathrm{FA}_{90-}$ Gpink mixtures

According to the Chart 5 , there is a reduction of porosity in the alkali-activated mixtures (FA, FA $100-\mathrm{G}, \mathrm{FA}_{90} \mathrm{G}_{\text {pink }}$ ), compared to the mixture without activation (FA-W), with the largest difference to appear at the age of 90 days. The addition of the pigments does not seem to affect the results of the alkali-activated mixtures (FA, FA $100-G, F_{90}-G_{\text {pink }}$. This porosity reduction goes with the increased values of strength for alkali-activated mixtures.

\subsubsection{Volume Deformation}

Chart 6, presents the results of volume deformation of mixtures at age $28-\mathrm{d}$.

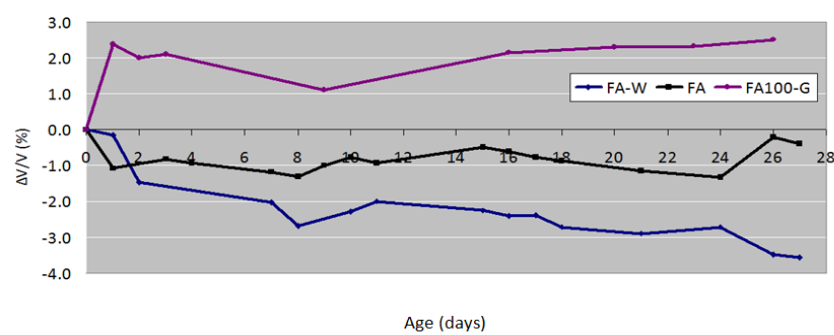

Chart 6: Volume deformation $\Delta \mathrm{V} / \mathrm{V}(\%)$ of FA-W, FA and $\mathrm{FA}_{100}-\mathrm{G}$ mixtures

The specimens without the use of the alkaline activator (FA$\mathrm{W})$ and those with the alkaline activator and without the glass aggregates (FA) appear to have a volume deformation that is stabilized after the age of 7 days. On the contrary, the mixture with the alkaline activator and the glass aggregates $\left(\mathrm{FA}_{100}-\mathrm{G}\right)$ seems to stabilize from the $3^{\mathrm{d}}$ day with a display of swelling, perhaps due to the alkali-silica reaction.

\subsection{Testing slabs $(200 \times 200 \times 25)(\mathrm{mm})$}

\subsubsection{Flexural Strength}

Three slab samples were tested according to EN 1338 for the determination of flexural strength at the ages of 7,28 and 90 days. The results of the test are shown in Chart 7.

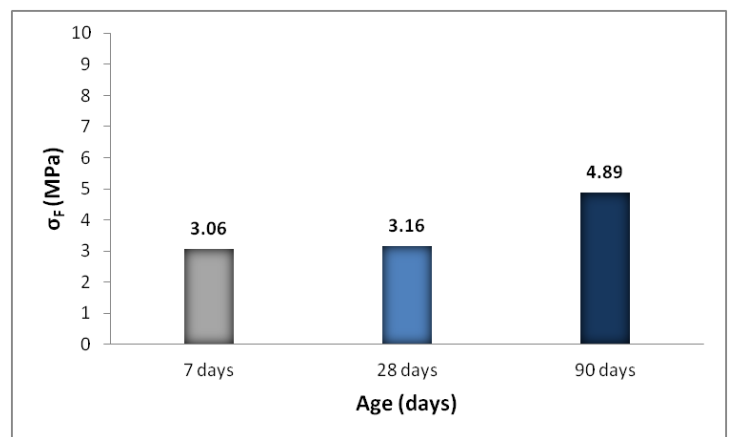

Chart 7: Flexural strength of three slabs 200x200x25(mm) Flexural strength at 28-d age reaches the level of $3.16 \mathrm{MPa}$ (>2.9 MPa limit value).

\subsubsection{Impact Strength}

A $700 \mathrm{~g}$ metallic ball was used for the test of the impact strength. Two slab samples were examined with the same method and gave the same result. The ball was dropped from several heights until the slab cracked (EN 1338). The results are shown in Table 4 and Figure 6.

Table 4: Results of the impact strength test

\begin{tabular}{|l|l|l|l|l|l|}
\hline Height $(\mathrm{cm})$ & 10 & 20 & 30 & 40 & 50 \\
\hline Sample 1 & - & - & - & - & fracture \\
\hline Sample 2 & - & - & - & - & fracture \\
\hline
\end{tabular}

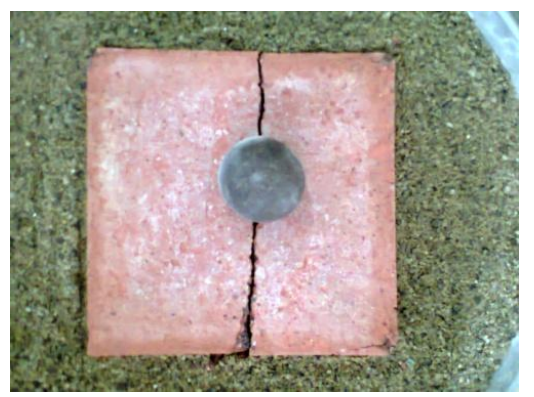

Fig. 6 : Sample of the slabs after testing

\subsubsection{Water Absorption}

Two samples were examined according to EN 1339 for the water absorption test. After immersing the specimens in potable water for a minimum period of 3 days, the slabs were weighed and put in an oven at a temperature of $105 \pm 5{ }^{\circ} \mathrm{C}$ for at least 3 days and weighed again. Table 5 presents the final results of the test.

Table 5: Results of water absorption test

\begin{tabular}{|l|l|l|l|}
\hline Weight $(\mathrm{g})$ & $\begin{array}{l}\text { After } \\
\text { Immersion }\end{array}$ & After drying & $(\%)$ \\
\hline Sample 1 & 2112.56 & 1839.005 & 14.88 \\
\hline Sample 2 & 2127.635 & 1894.72 & 12.29 \\
\hline
\end{tabular}


Both samples gave a result $>6 \%$, which is the limit according to EN 1339. That means that the open porosity of the surface of the slabs should be reduced by a proper treatment.

\subsubsection{Resistance to Abrasion}

The measurement of abrasion resistance was tested according to EN 1338 with a use of a proper machine filled with an abrasive material. The abrasive required for this test consists of a material comprising fused alumina (corundum) with a grit size of F80 in accordance with ISO 8486-1.

The results are given in the following Table 6.Requirements for abrasion resistance according to EN 1338 are given in Table 7.

Table 6: Results of resistance to abrasion

\begin{tabular}{|l|l|l|l|l|l|l|}
\hline \multirow{2}{*}{$\begin{array}{l}\mathrm{S} p / \\
\text { men }\end{array}$} & \multicolumn{2}{|l|}{$\begin{array}{l}\text { Measurement of the } \\
\text { groove }(\mathrm{mm})\end{array}$} & $\begin{array}{l}\text { Mean } \\
\text { value }\end{array}$ & $\begin{array}{l}\text { Corr. } \\
\text { result }\end{array}$ & $\begin{array}{l}\text { Final } \\
\text { mean } \\
\text { value. }\end{array}$ \\
\cline { 2 - 4 } & Right & Middle & Left & & 18.9 & \multirow{2}{*}{19.9} \\
\hline 1a & 19.1 & 18.8 & 17.9 & 18.6 & 18.9 \\
\hline
\end{tabular}

Table 7: Abrasion resistance classes according to EN 1338 According to the results, the slabs belong to class $4(19.9 \mathrm{~mm}$ $<20 \mathrm{~mm}$ limit value).

\begin{tabular}{|l|l|l|}
\hline Class & Marking & \\
\hline 1 & F & No performance measured \\
\hline 3 & H & $\leq 23 \mathrm{~mm}$ \\
\hline 4 & I & $\leq 20 \mathrm{~mm}$ \\
\hline
\end{tabular}

\subsubsection{Resistance to Freezing and Thawing}

Resistance to freezing and thawing was determined according to EN1338. A whole sample of the slabs was weighed $(2087.45 \mathrm{~g})$ and placed in a chamber for 6 weeks (about 30 cycles of freezing and thawing). After this period, the slab was weighed again (2027.96 g).

(L) is mass loss per unit area of the specimen, (M) is the mass of the total quantity of material scaled after 28 cycles, in kilograms, (A) $\mathrm{s}$ the area of the test surface in square meters. The result of the test is given below.

$$
\mathrm{L}=0.059 /\left(4 * 10^{-4}\right)=1.48 \mathrm{~kg} / \mathrm{m}^{2}\left(>0.5 \mathrm{Kg} / \mathrm{m}^{2}\right)
$$

No important changes were observed macroscopically on the surface of the slab during this period, contrary to the out of limit result (Figure 7).
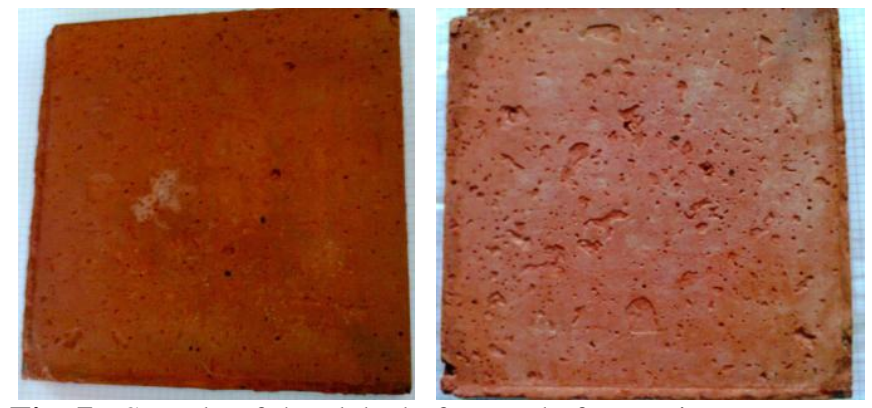

Fig. 7 : Sample of the slabs before and after testing

\subsection{Investigation of the Mechanisms Responsible for \\ Strength Development}

Samples from the above prismatic specimens were examined, in order to determine the mechanisms to which the cementing properties have been developed, at different ages, by using different methodologies.

Mineralogical analysis of crystal phases of fly ash, as well as the fly ash-based alkali activated products was performed with X-Ray Diffraction (XRD). The XRD diagrams of powdered samples were obtained with a Philips PW 1840 diffractometer using $\mathrm{CuKa}$ radiation with $2 \theta$ ranges from $2^{\circ}$ to $70^{\circ}$. Phase transformations through the absorptions of characteristic bands were identified by FTIR spectroscopy. The FTIR spectra diagrams were carried out by using a spectrometer (model Nicolet 6700) in the wave number range from 400 to $4000 \mathrm{~cm}^{-1}$ and $\mathrm{KBr}$ pellet technique. Specimens were prepared by mixing $1 \mathrm{mg}$ of sample in $300 \mathrm{mg}$ of $\mathrm{KBr}$. Finally, for the characterization of the surface morphology and the analysis of elemental composition a JOEL JSM 840A model scanning electron microscope (SEM/EDS) was used.

\subsubsection{Mineralogical Analysis of Crystal Phases by X- Ray Diffraction (XRD).}

Mineralogical analysis by XRD of fly ash-based mixture FA$\mathrm{W}$ (with water) and fly ash-based alkali-activated mixtures FA (without glass) and $\mathrm{FA}_{90}-\mathrm{G}_{\text {pink }}$ (with glass) at 28-d age is shown in Chart 8. 


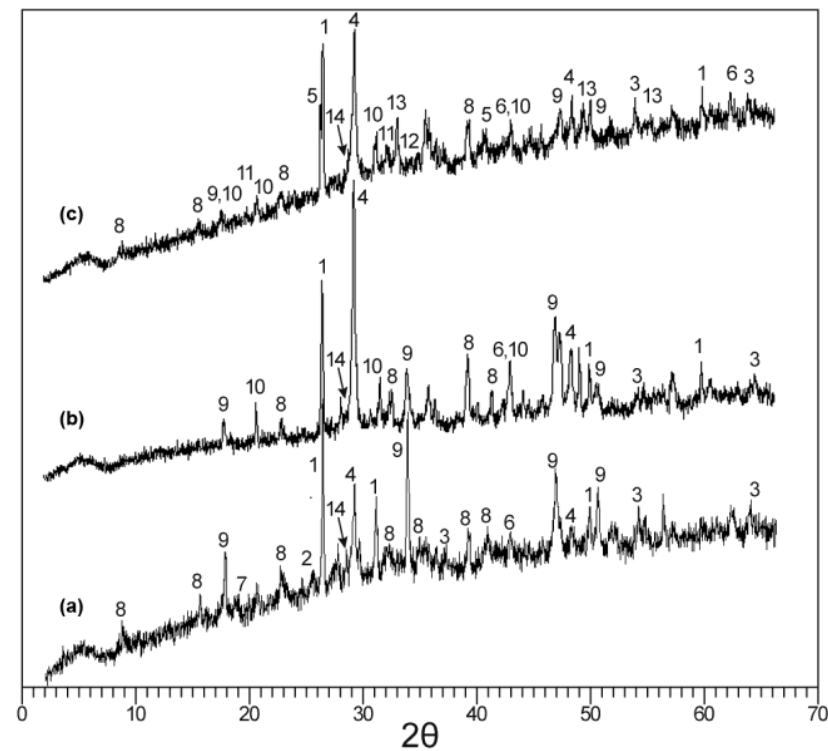

Chart 8: XRD diagram of hydrated fly ash mixture (a) FA$\mathrm{W}$ and alkali activated mixtures (b) FA, (c) $\mathrm{FA}_{90}-\mathrm{G}_{\text {pink }}$ at 28d age; (1) quartz, (2) anhydrite, (3) lime, (4) calcite, (5) mullite, (6) periclase, (7) feldspars, (8) ettringite, (9) portlandite, (10) herscelite, (11) thenardite, (12) pirssonite,

(13) hematite and (14) C-S-H

As it is shown, the mixtures are transformed to an almost amorphous material whereas micro-crystallized calciumsilicate, calcium-aluminate stable complex compounds (all expressed as $\mathrm{C}-\mathrm{S}-\mathrm{H})$ were present.

The formation of all these compounds were registered between $2 \theta=25^{\circ}-35^{\circ}$. The presence of this hump partially is due to the amorphous aluminosilicate gel (N-A-S-H), [13]. It is obvious that, the hump, in the XRD diagrams in the case of alkali-activated mixtures with glass cullet appears shifted toward higher values, and because of the amorphous nature of the glass which is added. In this case, the presence of a little amount of sodium carbonate like pirssonite $\left(\mathrm{Na}_{2} \mathrm{Ca}\left(\mathrm{CO}_{3}\right)_{2} \cdot 2 \mathrm{H}_{2} \mathrm{O}\right)$, was also detected. Additionally, in all mixtures were detected ettringite, because of the high sulfates level in the fly ash, and especially for the alkaliactivated mixtures some new crystalline phases (zeolites) such as herschelite $\left(\mathrm{NaAlSi}_{2} \mathrm{O}_{6} \cdot 3 \mathrm{H}_{2} \mathrm{O}\right)$ [14]. For all these reasons, the alkali-activated mixtures based on calcareous fly ash are expected to contain $\mathrm{C}-\mathrm{S}-\mathrm{H}$ phases, similar to those found in the mixture of hydrated fly ash and the precipitation of N-A-S-H gel as primary reaction with zeolite crystallizing [15-17]. Specifically, for the $\mathrm{FA}_{90}-\mathrm{G}_{\text {pink }}$ mixture the presence of hematite could be due to the addition of pigment.

\subsubsection{Phase Transformations through the}

\section{Absorptions of Characteristic Bands by FTIR Spectroscopy.}

The phase transformations through the absorptions of characteristic bands of raw fly ash $\mathrm{F}$ and alkali-activated mixtures $F A$ and $F A_{90}-G_{\text {pink }}$ at 28-d age are shown in FTIR spectrum in Chart 9.

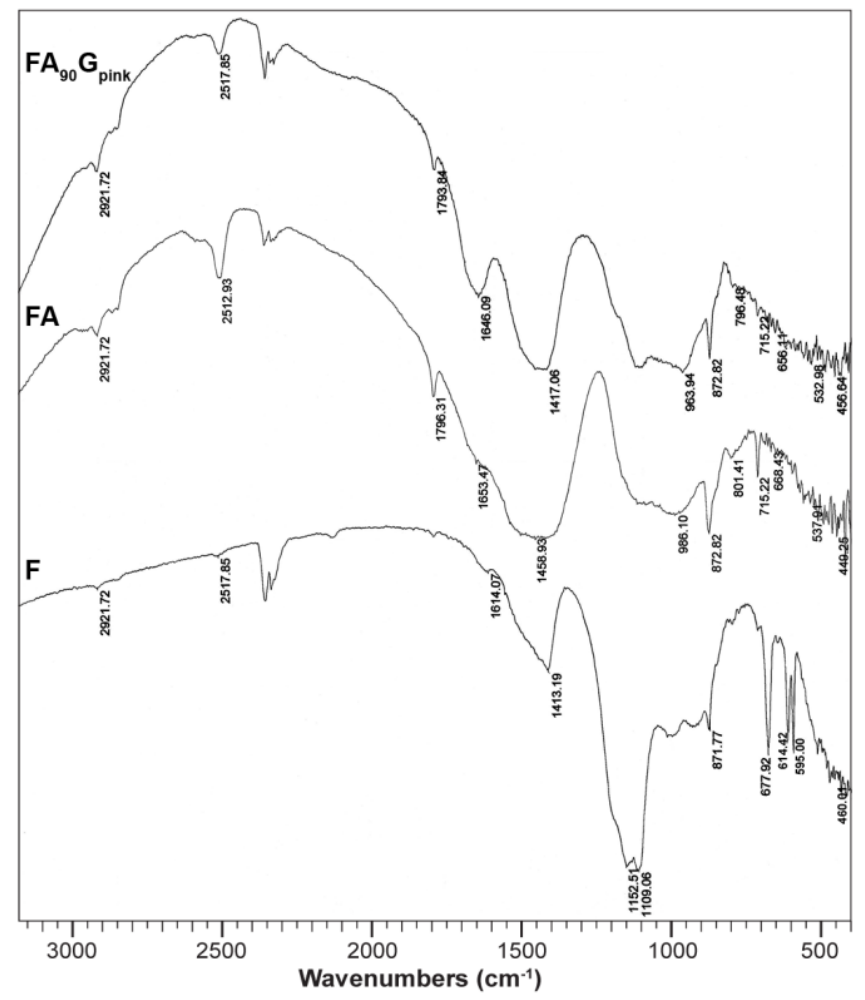

Chart 9: FTIR spectrum for $F$ and FA, $F_{90}-G($ pink) mixtures at 28-d age

The most characteristic difference observed between the FTIR spectrum of raw fly ash and FTIR spectra of alkaliactivation fly ash-based mixtures concerning the T-O band ( $\mathrm{T}=\mathrm{Si}$ or $\mathrm{Al}$ stretching vibrations). This band that is appeared as a broad band at about $1109 \mathrm{~s} \mathrm{~cm}^{-1}$ in the FTIR spectrum of fly ash $\mathrm{F}$ changes in shape and shifts to lower frequencies 986s, br $\mathrm{cm}^{-1}$ and $963 \mathrm{~s}, \mathrm{br} \mathrm{cm}^{-1}$ respectively in the FTIR spectra of mixtures FA and $F_{90}-G_{\text {pink }}$ indicating the formation of the amorphous aluminosilicate gel phase, during alkali-activation process [18]. Generally, major changes are observed in region $560-900 \mathrm{~cm}^{-1}$, where peaks, which refer to a range of bonds $\mathrm{Si}-\mathrm{O}-\mathrm{Si}$, disappear (dissolution of amorphous silica material) and peaks, which refer to stretching vibrations of Si-O-H, Si-O-Si and Al-O-Si, begin to appear, probably due to the creation of a new material of aluminosilicate nature (amorphous or poorly crystallized material) [6], [17]. In addition, the broad band at $460 \mathrm{w} \mathrm{cm}^{-1}$ becomes sharper and is observed at $449 \mathrm{w}-\mathrm{m} \mathrm{cm}^{-1}$ of FA and at $456 \mathrm{w}-\mathrm{m} \mathrm{cm}^{-1}$ of $\mathrm{FA}_{90}-\mathrm{G}_{\text {pink }}$, indicating a decrease in amorphous silicates and an increase in the crystalline silicates [19].

\subsubsection{Analysis of Microstructure and Elemental}

\section{Composition by Scanning Electron Microscope (SEM/EDS)}

In Figure 8 is given SEM/EDS analysis for hydrated mixture FA-W at 28-d age. 


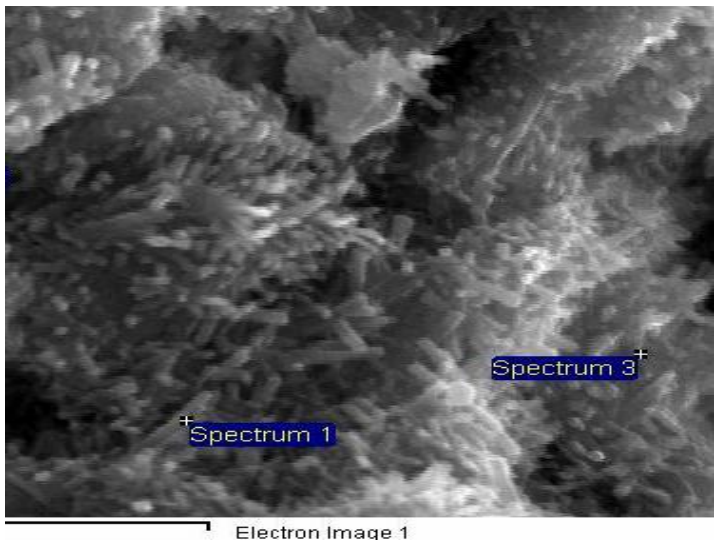

\begin{tabular}{|l|l|l|}
\hline Spectrum & Spectrum 1 & Spectrum 3 \\
\hline In stats. & Yes & Yes \\
\hline $\mathrm{Na}$ & 0.72 & 0.59 \\
\hline $\mathrm{Mg}$ & 10.38 & 8.63 \\
\hline $\mathrm{Al}$ & 9.99 & 9.51 \\
\hline $\mathrm{Si}$ & 16.16 & 19.07 \\
\hline $\mathrm{S}$ & 17.21 & 13.48 \\
\hline $\mathrm{K}$ & 0.40 & 0.65 \\
\hline $\mathrm{Ca}$ & 43.84 & 46.37 \\
\hline $\mathrm{Fe}$ & 2.76 & 1.72 \\
\hline
\end{tabular}

Fig. 8: SEM/EDS analysis for hydrated mixture FA-W at 28d age

By the SEM/EDS analysis of FA-W mixture, crystals of ettringite, $\mathrm{Ca}_{6} \mathrm{Al}_{2}\left(\mathrm{SO}_{4}\right)_{3}(\mathrm{OH})_{12} \cdot 26 \mathrm{H}_{2} \mathrm{O}$, are detected according to the ratio of $\mathrm{Ca} / \mathrm{S}$ and $\mathrm{Ca} / \mathrm{Al}$. This is also confirmed from the XRD analysis which is shown in chart 6 .

In Figure 9 is given SEM/EDS analysis for alkali-activated mixture $\mathrm{FA}_{90}-\mathrm{G}_{\text {pink }}$.

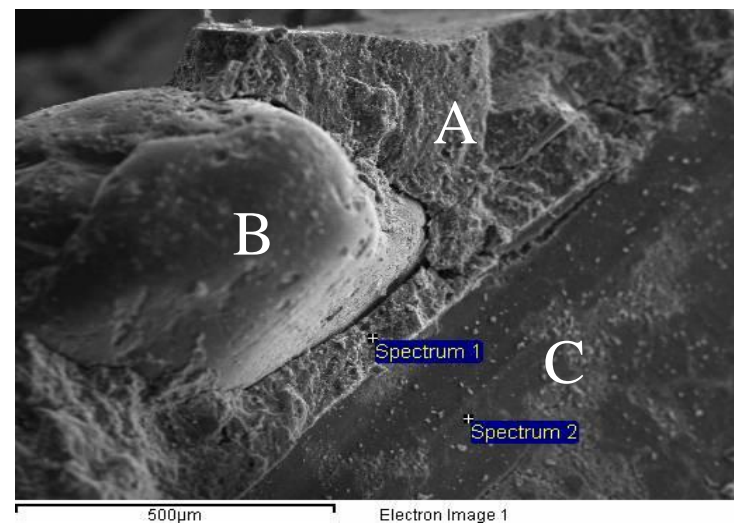

\begin{tabular}{|l|l|l|}
\hline Spectrum & Spectrum 1 & Spectrum 2 \\
\hline In stats. & Yes & Yes \\
\hline $\mathrm{Na}$ & 8.26 & 7.55 \\
\hline $\mathrm{Mg}$ & 6.12 & 2.52 \\
\hline $\mathrm{Al}$ & 7.62 & 4.58 \\
\hline $\mathrm{Si}$ & 31.35 & 56.65 \\
\hline $\mathrm{S}$ & 4.83 & 3.89 \\
\hline $\mathrm{K}$ & 0.89 & 0.28 \\
\hline $\mathrm{Ca}$ & 35.16 & 22.80 \\
\hline $\mathrm{Fe}$ & 5.76 & 1.73 \\
\hline
\end{tabular}

Fig. 9: SEM/EDS analysis for alkali-activated mixture $\mathrm{FA}_{90^{-}}$ $\mathrm{G}_{\text {pink }}$ at 28 -d age

It is obvious that the fly ash gel (A) is the binder between the grain of sand $(B)$ and the glass aggregate $(C)$. The interface of the fly ash gel and the grain of sand, seem to be loose with a possible creation of fractures. On the contrary, between the fly ash gel and glass aggregate a good cohesion seems to appear. Spectrum 2 in Figure 9 shows that the region $\mathrm{C}$ of glass contains mostly $\mathrm{Si}$ and $\mathrm{Ca}$ and $\mathrm{Na}$ in a smaller percentage. Compared to Spectrum 1 in Figure 3, here it is clear that region $\mathrm{C}$ of glass has undergone a partial dissolution of silicon [20]. Same elements are found in the range of the fly ash gel (region A-Spectrum 1 in Figure 9). In addition, ion of $\mathrm{Si}$ and $\mathrm{Na}$ are also available from the alkaline activator. Likewise, the Si/Ca ratio $(\sim 0.9)$ of the amorphous gel reaches a higher level than the $\mathrm{Si} / \mathrm{Ca}$ ratio $(\sim 0.4)$ of the hydrated fly ash, FA-W (Spectrum 1 and 3 in Figure 2. Finally, the $\mathrm{Na} / \mathrm{Al}$ ratio, which in the FA-W is approximately 0.1 , in the amorphous gel, increases to 1.01 , mainly due to the availability of elemental sodium from the alkaline solution of the activator.

\section{CONCLUSIONS}

The mechanism of alkaline activation contributes to higher mechanical strengths and positively influences the early strength development of the mixtures. However, the increase of compressive strength continues with time because of the hydraulic behavior of the fly ash, due to the high levels of $\mathrm{CaO}_{\mathrm{f}}(10.1 \% \mathrm{w} / \mathrm{w}$.) The addition of glass aggregates seems to have a positive effect in strength development and in the aesthetic value of the slabs. Fly ash based alkali-activated mixture with glass, shows compressive strength $\sim 15 \mathrm{MPa}$ at 28-d age compared to the one without glass cullet (8 MPa).Volume deformation of the alkaline activated mixtures stabilizes in early age and is less than $3 \%$.

Furthermore, using the alkaline-activated mixture, colored slabs were prepared with sufficient flexural and impact strength and good resistance to abrasion. Also the test of resistance to freezing and thawing seems not to affect significantly the surface of the slabs; nonetheless the value of resistance is out of scale $\left(>0.5 \mathrm{Kg} / \mathrm{m}^{2}\right)$. Based on the results, it could be firstly estimated that precast products of required characteristics may be manufactured by geopolymerization of fly ash.

A first investigation of the microstructure and mechanisms of alkali activation showed that hydration products due to the self-cementing character of fly ash are in parallel formed apart from the amorphous aluminosilicate gel. Therefore, calcium silicate and calcium aluminate hydrates $(\mathrm{C}-\mathrm{S}-\mathrm{H})$ as well as ettringite are detected by XRD while the main absorptions of $\mathrm{Si}-\mathrm{O}, \mathrm{Al}-\mathrm{O}$ are determined by FTIR spectrum. From the SEM/EDS analysis, the finer fraction of glass cullet seems to be dissolved and participate to the geopolymeric matrix, contributing to the increase of the mechanical strength. 
Finally, the pigment that was used did not seem to affect significantly the strength development and gave the desired colour tone to the mixture.

\section{REFERENCES}

[1]. Davidovits J, "Inorganic polymeric new materials", Jou.nal of Thermal Analysis, Vol. 37, 1991, Page(s): 16331656.

[2]. Xu H and Van Deventer J S J, "The geopolymerization of alumino-silicate minerals", Int J Miner Process, Vol. 59, 2000, Page(s): 247-266.

[3]. Swanepoel J C and Strydom C A, "Utilization of fly ash in a geopolymeric material", Appl Geochem, Vol. 17, 2002, Page(s): 1143-1148.

[4]. Van Jaarsveld J G S, Van Deventer J S J and Lukey G G, "The effect of composition and temperature on the properties of the fly ash -and kaolinite- based geopolymers", Chem Eng J, Vol. 89, 2002, Page(s): 63-73.

[5]. Davidovits J, "Chemistry of geopolymeric systems, terminology”, Geopolymer '99 Int. Conf., France, 1999, Page(s): 9-40.

[6]. Palomo A, Grutzeck M W and Blanco M T, "Alkaliactivated fly ashes, a cement for the future", Cem Concr Res, Vol. 29, No. 8, 1999, Page(s): 1323-1329.

[7]. Fernandez-Jimenez A, Palomo A and Criado M, "Microstructure development of alkali-activated fly ash cement: a descriptive model", Cem Concr Res, Vol. 35, 2005, Page(s): 1204-1209.

[8]. Senol A, Bin-Shafique M D S, Edil T B and Benson C $\mathrm{H}$, "Use of class $\mathrm{C}$ fly ash for stabilization of soft subgrade", ACE proceedings, 2002, Page(s): 96372.

[9]. Malhotra V M, Mehta P K, "High-Performance, HighVolume Fly Ash Concrete: Materials, Mixture Proportioning, Properties, Construction Practice, and Case Histories", Marquardt Printing Ltd., Ottawa, Canada, 2002, Page(s): 1417.

[10]. Papayianni I and Konopissi S, "Study on Geopolymerization of High Lime Fly Ashes", Concrete in the Low Carbon Era, $8^{\text {th }}$ Int. Conf., Dundee, UK, 2012, Page(s): 519-533.

[11]. Chindaprasirt $\mathrm{P}$, Chareerat $\mathrm{T}$ and Sirivivatnanon V, "Workability and strength of coarse high calcium fly ash geopolymer", Cem Concr Compos, Vol. 29, 2007, Page(s): 224-229.

[12]. Papayianni I and Karkantelidou F, "Performance of Superplasticizers in mixed type binding systems", Superplasticizers and other Chemical Admixtures in Concrete, $9^{\text {th }}$ CANMET/ACI Int. Conf., Seville, 2009

[13]. Criado M, Palomo A and Fernandez-Jimenez A, "Alkali activation of fly ashes. Part 1: Effect of curing conditions on the carbonation of the reaction products", Fuel, Vol. 84, 2005, Page(s): 2048-2054.

[14]. Fernandez-Jimenez A, Palomo A, "Composition and microstructure of alkali activated fly ash binder: Effect of the activator", Cem Concr Res, Vol. 35, 2005, Page(s): 19841992.

[15]. A. Fernández-Jiménez, A. Palomo, Characterization of fly ashes. Potencial reactivity as alkaline cements, FUEL, Vol. 82 No 18 (2003), Page(s): 2259-2265.
[16]. Caijun Shi, A. Fernández Jiménez and A. Palomo, New Cements for the $21^{\text {st }}$ Century, The pursuit of an alternative to Portland cement Cement and Concrete Research Vol. 41 (2011), Page(s): 750-763

[17]. J. Provis and J.S.J. van Deventer, Geopolymers, structure, processing, properties and industrial applications Edited by J. Provis and J.S.J. van Deventer, Woodhead Publishing Limited, (2009) ISBN 978-1-84569-449-4

[18]. W.K.W. Lee and J.S.J van Deventer, The effects of inorganic salt contamination on the strength and durability of geopolymers, Colloids Surf. A 212 (2002), Page(s):27-44.

[19]. Mozgawa W, Sitarz M and Rokita M, "Spectroscopic studies of different aluminosilicate structures", J Mol Struct, Vol. 511-512, 1999, Page(s): 251-257.

[20]. Drosou CA, Aniktomati E and Moutsatsou A K, "Glass cullet: an effective or an inert by-product?" Utilization of industrial by-products in construction, $3^{\text {rd }}$ Conf., Greece, 2012, Page(s): 153-164.

\section{BIOGRAPHIES}

I Papayianni is currently Professor and Director of the Laboratory of Building Materials at the Civil Engineering Dept. of the Aristotle University of Thessaloniki, Greece. She is a member of ACI and RILEM Committees and the scientific responsible of many National and European Research Projects. Her specialist research fields include concrete technology, supplementary materials and repair materials.

S Konopisi is a Chemist MSc and a $\mathrm{PhD}$ candidate at the Laboratory of Building Materials at the Civil Engineering Dept. of the Aristotle University of Thessaloniki, Greece. She has participated in several research projects on concrete chemistry and on conservation and restoration of monuments. Her recently specialist areas of research include alkali-activation and construction material characterization.

K. Datsiou received the M. Eng. degree in civil engineering from the Aristotle University of Thessaloniki (AUTh), Thessaloniki, Greece in 2012. She is currently pursuing the Ph.D. degree at the Glass and Façade Technology Research Group at the University of Cambridge. Her research interests include structural use of glass, cold bending of glass, toughened glass durability and geopolymers.

F. Kesikidou is a student at the Civil Engineering Dept. of the Aristotle University of Thessaloniki, Greece. She is currently working as a laboratory assistant at the Laboratory of Building Materials, in the project of "Utilization of Sustainable Construction and Toxic compounds' Immobilization". Her diploma thesis was in the field of alkali-activation. 